\title{
Penerapan Tata Kelola Teknologi Informasi dan Pengukuran Maturity Level Menggunakan Domain MEA (Monitor, Evaluate Dan Assess) Dengan Framework COBIT (Studi Kasus: Sistem Informasi Akademik AIKOM Ternate)
}

\author{
Junaidi Sabtu ${ }^{*}$ \\ ${ }^{1}$ Akademi Ilmu Komputer Ternate \\ *juned.end@gmail.com
}

\begin{abstract}
The Academy of Computer Science (AIKOM) Ternate has implemented information technology in the Academic Information System (SIAK) section, which is an important part of connecting management with all stakeholders. Formulation of the problems raised in this study includes how to classify problems into statements that are in accordance with COBIT 5 framework and how to determine and measure the maturity level of IT governance at AIKOM Ternate by using the MEA (Monitor, Evaluate and Assess) domain. The researcher used a questionnaire instrument to measure the maturity level of IT governance at AIKOM Ternate. The sample used was 13 people including the leadership and several staff. Based on the calculation of the maturity level of IT governance, a value for MEAO1 (Performance and Conformance) is obtained at 3.2, MEAO2 (The System of Internal Control) of 3.3, and MEA03 (Compliance With External Requirements) of 3.3, which means that each subdomain is at level 3, which means Established Process, so that the average MEA maturity level is 3.3, which is in the Established Process status.The results of the recommendations of this study are for MEA01 subdomains need to establish guidelines and SOPs for the implementation of monitoring and evaluation of SIAK, there needs to be monitoring from the leadership of the duties of each stakeholder and set the standard reporting process from data collection, time and feedback from report results. The recommendation for the MEA02 subdomain is that AIKOM Ternate must develop a mechanism for controlling SIAK, develop SIAK quality assurance standards and carry out periodic evaluations of quality assurance. And recommendations for the MEA03 subdomain carry out periodic reviews and make guidelines and SOPs related to SIAK changes based on external changes
\end{abstract}

Keywords: Governance, Management, COBIT 5, MEA

\begin{abstract}
Abstrak
Akademi Ilmu Komputer (AIKOM) Ternate telah menerapkan teknologi informasi pada bagian Sistem Informasi Akademik (SIAK), yang merupakan bagian penting untuk menghubungan manajemen dengan seluruh stakeholder. Perumusan permasalahan yang diangkat pada penelitian ini meliputi bagaimana mengklasifikasikan masalah menjadi pernyataan yang sesuai dengan framework COBIT 5 serta bagaimana menentukan dan mengukur tingkat kematangan tata kelola TI di AIKOM Ternate dengan menggunakan domain MEA (Monitor, Evaluate and Assess). Peneliti menggunakan instrumen kuisioner untuk mengukur tingkat kematangan tata kelola TI di AIKOM Ternate. Sampel yang digunakan ada 13 orang mencakup jajaran pimpinan dan beberapa staf. Berdasarkan hasil perhitungan tingkat kematangan tata kelola TI, diperoleh nilai untuk MEA01 (Performance and Conformance) sebesar 3.2, MEA02 (The System of Internal Control) sebesar 3.3, dan MEA03 (Compliance With External Requirement) sebesar 3.3, yang berarti masing-masing subdomain berada pada tingkat 3, yang berarti Established Process, sehingga rata-rata nilai tingkat kematangan MEA adalah sebesar 3.3 yaitu berada pada status Established Process. Hasil rekomendasi dari penelitian ini adalah untuk subdomain MEA01 perlu menetapkan pedoman dan SOP pelaksanaan monitoring dan evaluasi terhadap SIAK, perlu ada monitoring dari pimpinan terhadap tugas dari masing-masing stakeholder serta menetapkan stadar proses pelaporan dari pengempulan data, waktu dan feedback dari hasil laporan. Rekomendasi untuk subdomain MEA02 adalah AIKOM Ternate harus menyusun mekanisme proses pengontrolan SIAK, menyusun standar penjaminan mutu SIAK dan melaksanakan evaluasi secara berkala terhadap penjaminan mutu. Dan rekomendasi untuk subdomain MEA03 melakukan peninjauan ulang secara berkala dan membuat pedoman dan SOP terkait perubahan SIAK berdasarkan perubahan eksternal.
\end{abstract}

Kata kunci: Tata, Kelola, COBIT 5, MEA 


\section{Pendahuluan}

\subsection{Latar Belakang}

Pemanfaatan TI oleh perguruan tinggi menjadi salah satu faktor penting demi menunjang proses berjalannya manajemen akademik. TI memberikan banyak keuntungan penyimpanan, pengiriman, pengaksesan, dan pengolahan informasi ataupun data menjadi semakin cepat [1].

Tata kelola TI merupakan prosedur dan kumpulan proses yang bertujuan untuk memastikan kesesuaian penerapan TI dengan dukungan terhadap pencapaian tujuan organisasi, dengan cara mengoptimalkan keuntungan yang ditawarkan oleh TI, mengontrol penggunaan sumber daya TI, dan mengelola resiko terkait dengan TI. TI tidak lagi dipandang sebagai pendukung proses bisnis suatu organisasi, tetapi sudah dipandang sebagai bagaian dari strategi bisnis organisasi, maka tata kelola TI dapat mengontrol semua solusi TI untuk menjaga keselarasan antara TI dengan strategi organisasi guna mencapai tujuan bisnis organisasi.

Akademi Ilmu Komputer (AIKOM) Ternate merupakan salah satu perguruan tinggi swasta di kota Ternate yang menyelenggarakan pendidikan di bidang Teknologi Informasi dan Sistem Informasi, tetapi belum memanfaatkan peran tata kelola TI sebagai pencapaian kenerja, mengelola aset dan transformasikan pelayanan akademik yang lebih efektif dan efisien untuk menunjang strategi bisnis. Namun saat ini tata kelola TI yang baik (Good Governance) belum diterapkan baik sehingga tidak ada kejelasan dari kebijakan tata kelola TI dan tingkat layanan TI.

COBIT 5 telah melakukan penggabungan pemikiran terbaru dalam teknik tata kelola perusahaan dan manajemen, dan menyediakan prinsip, praktik, alat analisis, dan model yang dapat diterima secara global untuk membantu meningkatkan kepercayaan dan nilai dari sistem informasi. COBIT 5 membangun dan memperluas COBIT 4.1 dengan mengintegrasikan kerangka utama lainnya, standar dan sumber daya, termasuk ISACA's Val IT, Information Technology Infrastructure Library (ITIL) dan standar yang berkaitan dengan International Organization for Standardization (ISO). Secara sederhana COBIT 5 membantu perusahaan menciptakan nilai optimal dari TI dengan cara menjaga keseimbangan antara mendapatkan keuntungan dan mengoptimalkan tingkat resiko dan penggunaan sumber daya.

Berdasarkan uraian latar belakang diatas maka peneliti mendapatkan beberapa permasalahan, Bagaimana melakukan klasifikasi masalah-masalah menjadi pernyataan-pernyataan yang disesuaikan dengan framework COBIT 5 untuk menentukan penggunaan Domain di AIKOM Ternate? Bagaimana menentukan dan mengukur tingkat kematangan tata kelola TI di AIKOM Ternate berdasarkan domain MEA (Monitor, Evaluate, and Assess) sesuai framework COBIT 5? Bagaimana menghasilkan rekomendasi terhadap sistem tata kelola TI yang lebih baik berdasarkan hasil tingkat kematangan dengan domain MEA sesuai framework COBIT 5?

Dari penelitian diharapkan mempunyai manfaat Ilmiah dapat memberikan rekomendasi terhadap tata kelola TI dengan framework COBIT 5 dan dapat meningkatkan TI pada AIKOM Ternate. Serta dapat dijadikan acuan untuk meningkatan tata kelola TI saat ini dan masa mendatang, lebih efisien, dan lebih efektif dalam memberikan pelayanan yang lebih baik kepada para mahasiswa.

\subsection{Model Penilaian Kapabilitas Proses pada COBIT 5}

Setiap atribut mendefinisikan aspek tertentu dari kapabilitas proses. Kombinasi pencapai atribut proses tersebut akan menentukan level kapabilitas proses. Tingkat kapabiliti pada COBIT 5 dimodelkan seperti pada Gambar 1. 


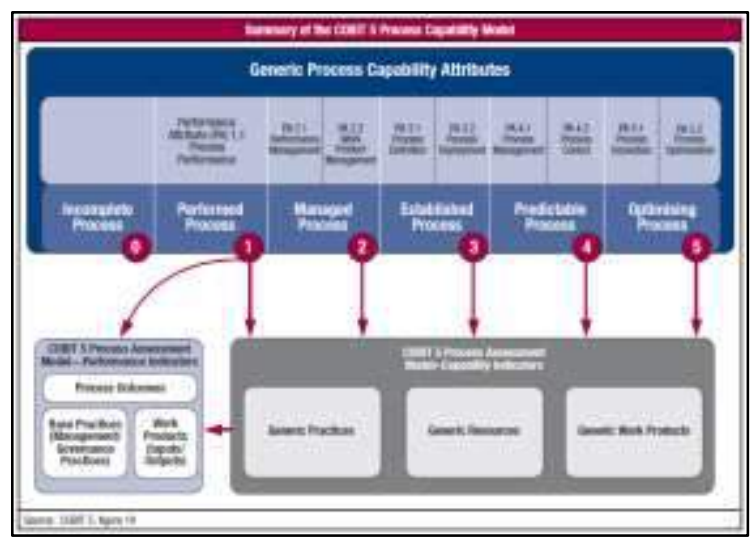

Gambar 1. Model Kapabiliti Proses COBIT 5 [2]

\subsection{Enablers}

Enablers adalah sekumpulan faktor yang mempengaruhi sesuatu yang akan dikerjakan oleh organisasi [3]. COBIT 5 enablers dijelaskan oleh framework di dalam 7 kategori enablers, yaitu:

1. Prinsip, Kebijakan dan Kerangka Kerja (Principles, Policies and Framework) yaitu alat atau pendorong untuk menerjemahkan tingkah laku ke dalam panduan praktis untuk manajemen seharihari.

2. Proses (Processes) yaitu menjelaskan tentang sekumpulan kegiatan yang terorganisir untuk mencapai tujuan tertentu dan menghasilkan sekumpulan keluaran dalam mendukung pencapaian tujuan IT.

3. Struktur Organisasi (Organizational Structures) yaitu etitas dalam organisasi sebagai kunci dalam membuat keputusan.

4. Budaya, Etika dan Perilaku (Culture, Ethics and Behaviour) yaitu merupakan faktor keberhasilan dalam kegiatan tata kelola dan manajemen.

5. Infromasi (Information) yaitu Informasi dalam organisasi terdiri dari informasi yang dihasilkan dan digunakan agar ogarnisasi dapat berlajan dengan baik.

6. Layanan, Infrastruktur dan Aplikasi (Service, Infrastructure and Applications) yaitu dapat melibatkan infastruktur teknologi dan aplikasi yang menyediakan proses dan layanan teknologi informasi bagi organisasi.

7. Orang, kemampuan dan kompentensi (People, Skills and Competencies) berhubungan dengan seseorang dan kebutuhan untuk memenuhi semua aktifitas untuk mencapai kesuksesan dan membuat keputusan yang tepat dengan langkah yang tepat.

\subsection{RACI Chart}

RACI chart adalah matrik dari semua aktivitas dan wewenang pada organisasi yang membantu dalam pengambilan keputusan [2]. Berikut penjelasan diagram RACI:

1. Responsible (Tanggung Jawab) yaitu siapa yang menyelesaikan tugas? Hal ini mengacu kepada peran dalam pengambilan keputusan pada kegiatan operasional, memenuhi kebutuhan dan menciptakan hasil yang diinginkan dari organisasi.

2. Accountable yaitu siapa yang bertanggung jawab atas keberhasilan tugas? Hal ini mengacu kepada peran dalam mempertanggungjawabkan secara keseluruhan atas tugas yang telah dilakukan.

3. Consulted yaitu siapa yang memberikan masukan? Hal ini mengacu kepada peran yang bertanggung jawab untuk memperoleh informasi dari unit internal maupun eksternal. Mampu mempertimbangkan masukan dan pengambilan tindakan yang tepat.

4. Informed yaitu siapa yang menerima informasi? Hal ini mengacu kepada peran yang bertanggung jawab dalam menerima informasi yang tetap untuk mengawasi setiap tugas yang dilakukan.

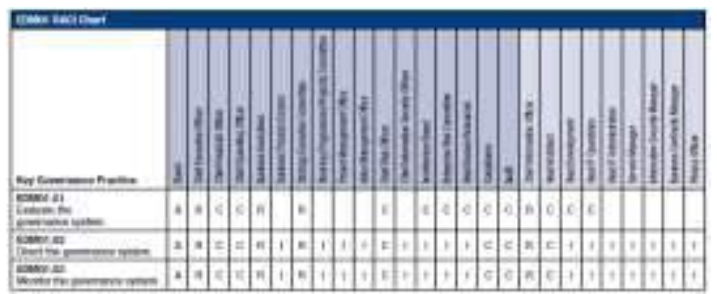

Gambar 2. Diagram RACI [2].

\section{Metoda Penelitian}

\subsection{Jenis, Sifat, dan Pendekatan Penelitian}

Jenis penelitian yaitu dengan menggunakan jenis pendekatan kuantitatif dan kualitatif. Pada pendekatan kuantitatif menggunakan model matematis dan proses pengukuran terhadap sebuah kejadian serta hubungannya, sedangkan pedekatan kualitatif adalah pendekatan berdasarkan kejadian 
alamiah dan menggunakan pendekatan dengan framework (kerangka kerja) COBIT 5.

\subsection{Metode Pengumpulan Data}

Pada penelitian ini peneliti melakukan beberapa metode pengumpulan data sebagai berikut:

1. Data Primer yaitu data yang diperoleh dari kuisioner yang diberikan kepada responden yang sudah dipilih dari populasi yang ada di tempat penelitian.

2. Data Sekunder adapun data yang digunakan dalam penelitian ini yaitu:

a. Studi Pustaka yaitu peneliti mencari sumber pustaka yang relevan untuk digunakan dalam penelitian ini yang di review dari jurnal penelitian dan buku.

b. Dokementasi yaitu peneliti mengumpulkan dokumen-dokumen yang relevan di tempat penelitian yakni, visi dan misi AIKOM Ternate, struktur organisasi dan dokumen pendukung yang lain.

c. Kuisioner adalah berupa pernyataanpernyataan dari domain MEA dan sub domainnya.

\subsection{Metode Analisis Data}

Data yang sudah dikumpulkan berdasar studi pustaka dan kuisioner, maka peneliti melakukan tahapan selanjutnya melakukan analisis data, di mana data kuisioner akan dianalisis dengan menggunakan skala Linkert dan Capability Level. Skala Linkert untuk menganalisis jawaban dari hasil pengisian kuisioner sesuai responden yang berada di AIKOM Ternate. Hasil perhitungan dengan skala Linkert akan dianalisis kembali dengan menggunakan Capability Level pada Framework COBIT 5 untuk memperoleh hasil atau mengetahui tingkat kematangan saat ini pada AIKOM Ternate dalam tata kelola TI. Adapun tahapan-tahapan COBIT 5 untuk menganalisis hasil dari skala Linkert.

\subsection{Alur Penelitian}

Dalam melakukan proses Tata Kelola TI pada AIKOM Ternate memiliki dua metode dengan beberapa tahapan seperti perincian pada Gambar 6 .

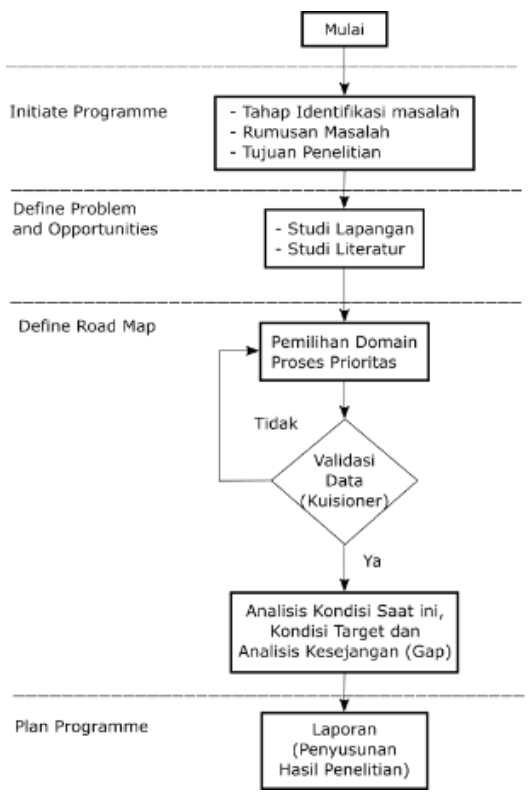

Gambar 3. Alur Penelitian

Bagian ini berisi diagram alur langkah penelitian secara lengkap dan terinci termasuk di dalamnya tercermin algoritma, rute, pemodelan-pemodelan, desain, yang terkait dengan aspek perancangan sistem.

Tabel 1. Tahapan-tahapan Penelitian

\begin{tabular}{|c|c|}
\hline $\begin{array}{l}\text { Tahapan } \\
\text { Penelitian }\end{array}$ & Penjelasan Tahapan Penelitian \\
\hline Initiate & Pada tahap ini peneliti melakukan \\
\hline Programme & $\begin{array}{l}\text { Identifikasi Masalah, Rumusan } \\
\text { Masalah dan Tujuan Penelitian. }\end{array}$ \\
\hline $\begin{array}{l}\text { Define } \\
\text { Problem } \\
\text { and } \\
\text { Opportunities }\end{array}$ & $\begin{array}{l}\text { Pada tahap ini peneliti melakukan } \\
\text { studi lapangan dan studi literatur } \\
\text { terkait dengan rumusan masalah } \\
\text { dari tahap initiate Programme. }\end{array}$ \\
\hline \multirow[t]{3}{*}{$\begin{array}{l}\text { Define Road } \\
\text { Map }\end{array}$} & $\begin{array}{l}\text { 1. Pada tahapan ini peneliti } \\
\text { melakukan pemilihan domain } \\
\text { proses sesuai dengan serta } \\
\text { menentukan model kuisioner } \\
\text { berdasar domain proses yang } \\
\text { dipilih. }\end{array}$ \\
\hline & $\begin{array}{l}\text { 2. Setelah kuisioner disebarkan } \\
\text { dalam tahap ini maka peneliti } \\
\text { melakukan validasi data sesuai } \\
\text { dengan hasil kuisioner yang } \\
\text { disebarkan. }\end{array}$ \\
\hline & $\begin{array}{l}\text { 3. Kemudian pada tahapan ini } \\
\text { peneliti bisa melakukan } \\
\text { Analisis GAP dan Target }\end{array}$ \\
\hline
\end{tabular}


Tahapan Penjelasan Tahapan Penelitian Penelitian

Capability Rating (Peringkat Kemampuan Target) untuk dapat mengahasilkan hasil penelitian, kemudian merekomendasikan perbaikain pada tahapan berikutnya.

Plan Pada tahapan ini peneliti

Progamme

memberikan rekomendasi

berdasarkan hasil temuan di

tahapan-tahapan sebelumnya. Di antaranya:

1. Rekomendasi Monitor, Evaluate, and Assess Performance and Conformance (MEA01).

2. Rekomendasi Monitor Evaluate, and Assess the System of the Internal Control (MEA02)

3. Rekomendasi Monitor Evaluate, and Assess Compliance with External Requirements (MEA03)

\subsection{Identifikasi Proses Teknologi Informasi \\ Di tahap ini dilakukan identifikasi proses teknologi Informasi dengan menggunakan COBIT 5.}

Tabel 2. Deskripsi Proses Teknologi Informasi

\begin{tabular}{|c|c|}
\hline Domain TI & Proses TI \\
\hline $\begin{array}{l}\text { Evaluate, } \\
\text { Direct and } \\
\text { Monitor }\end{array}$ & $\begin{array}{l}\text { EDM01, EDM02, EDM03, } \\
\text { EDM04, EDM05 }\end{array}$ \\
\hline $\begin{array}{l}\text { Align, Plan } \\
\text { and } \\
\text { Organize }\end{array}$ & $\begin{array}{l}\text { APO01, APO02, APO03, APO04, } \\
\text { APO05, APO06, APO07, APO08, } \\
\text { APO09, APO10, APO11, APO12, } \\
\text { APO13 }\end{array}$ \\
\hline $\begin{array}{l}\text { Build } \\
\text { Acquire } \\
\text { Implement }\end{array}$ & $\begin{array}{l}\text { BAI01, BAI02, BAI03, BAI04, } \\
\text { BAI05, BAI06, BAI07, BAI08, } \\
\text { BAI09, BAI10 }\end{array}$ \\
\hline $\begin{array}{l}\text { Deliver, } \\
\text { Service and } \\
\text { Support }\end{array}$ & $\begin{array}{l}\text { DSS01, DSS02, DSS03, DSS04, } \\
\text { DSS05, DSS06 }\end{array}$ \\
\hline $\begin{array}{l}\text { Monitor, } \\
\text { Evaluate and } \\
\text { Assess }\end{array}$ & MEA01, MEA02, MEA03 \\
\hline
\end{tabular}

SIAK ini belum memiliki sistem evaluasi secara rutin terhadap perencanaan dan perancangan SIAK, proses pembuatan serta pengaplikasian SIAK dan evaluasi kegiatan operasional SIAK. Sehingga penulis menggunkan domain MEA (Monitor, Evaluate, and Access) untuk melakukan monitoring dan evaluasi proses kerja SIAK AIKOM Ternate.

Tabel 3. Deskripsi Subdomain dan Proses TI pada Domain MEA

\begin{tabular}{|c|c|}
\hline \multicolumn{2}{|c|}{$\begin{array}{l}\text { MEA01: Monitor, Evaluate and Assess } \\
\text { Perfomance and Conformance }\end{array}$} \\
\hline MEA01.01 & Establish a monitoring approach. \\
\hline MEA01.02 & $\begin{array}{l}\text { Set performance and conformance } \\
\text { targets. }\end{array}$ \\
\hline MEA01.03 & $\begin{array}{l}\text { Collect and process performance } \\
\text { and conformance data. }\end{array}$ \\
\hline MEA01.04 & Analyse and report performance. \\
\hline MEA01.05 & $\begin{array}{l}\text { Ensure the implementation of } \\
\text { corrective actions. }\end{array}$ \\
\hline \multicolumn{2}{|c|}{$\begin{array}{l}\text { MEA02: Monitor, Evaluate and Assess the } \\
\text { System of Internal Control }\end{array}$} \\
\hline MEA02.01 & Monitor internal controls. \\
\hline MEA02.02 & $\begin{array}{l}\text { Review business process controls } \\
\text { effectiveness. }\end{array}$ \\
\hline MEA02.03 & Perform control self-assessments. \\
\hline MEA02.04 & $\begin{array}{l}\text { Identify and report control } \\
\text { deficiencies. }\end{array}$ \\
\hline MEA02.05 & $\begin{array}{l}\text { Ensure that assurance providers } \\
\text { are independent and qualified. }\end{array}$ \\
\hline MEA02.06 & Plan assurance initiatives. \\
\hline MEA02.07 & Scope assurance initiatives. \\
\hline MEA02.08 & Execute assurance initiatives. \\
\hline $\begin{array}{l}\text { MEA03: } M \\
\text { Compliance }\end{array}$ & $\begin{array}{l}\text { tor, Evaluate and Assess } \\
\text { ith External Requirement }\end{array}$ \\
\hline MEA03.01 & $\begin{array}{l}\text { Identify external compliance } \\
\text { requirements. }\end{array}$ \\
\hline MEA03.02 & $\begin{array}{l}\text { Optimise response to external } \\
\text { requirements. }\end{array}$ \\
\hline MEA03.03 & Confirm external compliance. \\
\hline MEA03.04 & $\begin{array}{l}\text { Obtain assurance of external } \\
\text { compliance. }\end{array}$ \\
\hline
\end{tabular}

\section{Hasil Penelitian}

\subsection{Analisis Pertanyaan Kuisioner}

Pada penelitian ini yang menjadi capability model adalah alat ukur untuk mengetahui kondisi proses IT pada SIAK AIKOM Ternate. Kegiatan pengukuran berdasarkan framework COBIT 5 ini 
menghasilkan penilaian tentang kondisi sekarang dari proses Monitor, Evaluate and Assess (MEA), yang terdiri dari Monitor, Evaluate, and Access Performance and Conformance (MEA01), Monitor, Evaluate and Access Perfomance the System of the Internal Control (MEA02), serta Monitor, Evaluate and Access Compliane with External Requirements (MEA03).

Pada pengukuran capability model ini digunakan pengambilan data melalui kuisioner. Responden yang dilibatkan untuk pengisian kuisioner terutama adalah pada unit kerja IT yang mengoperasikan secara langsung dan mengetahui masalah yang berkaitan dengaan proses terpilih, responden juga berasal dari unit kerja lain yang terkait.

\subsection{Analisis Responden}

Penentuan sampel didasarkan oleh model RACI (Responsibility, Accountability, Consult and Informed), dengan sampel yang digunakan sebanyak 13 orang responden karena dalam struktur organisasi belum adanya Unit yang menangani masalah TI.

Tabel 4. RACI Chart AIKOM Ternate

\begin{tabular}{|c|c|c|c|}
\hline No & $\begin{array}{l}\text { Key } \\
\text { Governance } \\
\text { Practice }\end{array}$ & Jabatan & Jumlah \\
\hline 1 & $\begin{array}{l}\text { Chief of } \\
\text { Executive } \\
\text { Officer }\end{array}$ & $\begin{array}{l}\text { Direktur } \\
\text { AIKOM } \\
\text { Ternate }\end{array}$ & 1 \\
\hline 2 & $\begin{array}{l}\text { Chief of } \\
\text { Information } \\
\text { Officer }\end{array}$ & $\begin{array}{l}\text { Wakil } \\
\text { Direktur }\end{array}$ & 3 \\
\hline 3 & $\begin{array}{l}\text { Chief of } \\
\text { Information } \\
\text { Officer }\end{array}$ & $\begin{array}{l}\text { Ka. Prodi } \\
\text { Manajemen } \\
\text { Informatika }\end{array}$ & 1 \\
\hline 4 & $\begin{array}{l}\text { Chief of } \\
\text { Information } \\
\text { Officer }\end{array}$ & $\begin{array}{l}\text { Ka. Prodi } \\
\text { Teknik } \\
\text { Komputer }\end{array}$ & 1 \\
\hline 5 & $\begin{array}{l}\text { Chief of } \\
\text { Information } \\
\text { Officer }\end{array}$ & Kepala BAAK & 1 \\
\hline 6 & $\begin{array}{l}\text { Chief of } \\
\text { Information } \\
\text { Officer }\end{array}$ & Kepala LP2M & 1 \\
\hline 7 & $\begin{array}{l}\text { Chief of } \\
\text { Information } \\
\text { Officer }\end{array}$ & Kepala LPM & 1 \\
\hline
\end{tabular}

\begin{tabular}{clll}
\hline No & $\begin{array}{l}\text { Key } \\
\text { Governance } \\
\text { Practice }\end{array}$ & Jabatan & Jumlah \\
\hline 8 & $\begin{array}{l}\text { IT } \\
\text { Administration }\end{array}$ & $\begin{array}{l}\text { Sekertaris } \\
\text { Prodi } \\
\text { Manajemen } \\
\text { Informatika }\end{array}$ & 1 \\
\hline 9 & $\begin{array}{l}\text { IT } \\
\text { Administration }\end{array}$ & $\begin{array}{l}\text { Sekertaris } \\
\text { Prodi Teknik } \\
\text { Komputer }\end{array}$ & 1 \\
\hline 10 & $\begin{array}{l}\text { IT } \\
\text { Administration }\end{array}$ & Staf BAAK & \\
\hline
\end{tabular}

Jumlah responden

\subsection{Perhitungan Tingkat Kematangan}

Data yang diperoleh dari kuesioner antara lain nilai rata-rata berdasarkan atribut jawaban dari semua responden, penilaian tingkat model capability process, dan representasi kondisi tata kelola TI di bagian SIAK pada AIKOM Ternate. Kuesioner menggunakan skala Likert yang mana responden akan memilih jawaban berdasarkan urutan angka yang mengandung definisi.

Tabel 5. Nilai Indeks Skala Likert pada Kuisioner

\begin{tabular}{cl}
\hline Nilai & Keterangan \\
\hline 1 & Sangat Tidak Setuju \\
\hline 2 & Tidak Setuju \\
\hline 3 & Cukup \\
\hline 4 & Setuju \\
\hline 5 & Sangat Setuju \\
\hline
\end{tabular}

Tabel 6. Level capability model

\begin{tabular}{cl}
\hline Nilai & Keterangan \\
\hline 5 & Optimising Process \\
\hline 4 & Predictable Process \\
\hline 3 & Established Process \\
\hline 2 & Managed Process \\
\hline 1 & Performed Process \\
\hline 0 & Incomplete Process \\
\hline
\end{tabular}

\subsection{Detail Nilai Tingkat Kematangan pada Setiap Subdomain}

Detail nilai tingkat kematangan setiap pada setiap subdomain MEA dari hasil kuesioner dapat dijelaskan sebagai berikut: 
Tabel 7. Hasil Perhitungan Kuisioner MEA01

\begin{tabular}{llc}
\hline Domain & Keterangan & Nilai \\
\hline MEA01.01 & $\begin{array}{l}\text { Establish a monitoring } \\
\text { approach }\end{array}$ & 3.3 \\
\hline MEA01.02 & $\begin{array}{l}\text { Set performance and } \\
\text { conformance targets }\end{array}$ & 2.7 \\
\hline MEA01.03 & $\begin{array}{l}\text { Collect and process } \\
\text { performance and conformance } \\
\text { data }\end{array}$ & 3.6 \\
\hline MEA01.04 & $\begin{array}{l}\text { Analyze and report performance } \\
\text { MEA01.05 }\end{array}$ & $\begin{array}{l}\text { Ensure the implementation of } \\
\text { corrective actions }\end{array}$ \\
\hline
\end{tabular}

\section{MEA01}

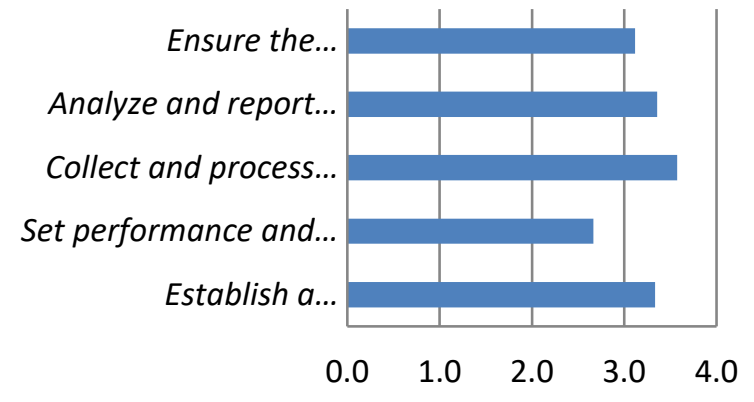

Gambar 4. Hasil Perhitungan Kuisioner MEA01 dalam Grafik

Tabel 8. Hasil Perhitungan Kuisioner MEA02

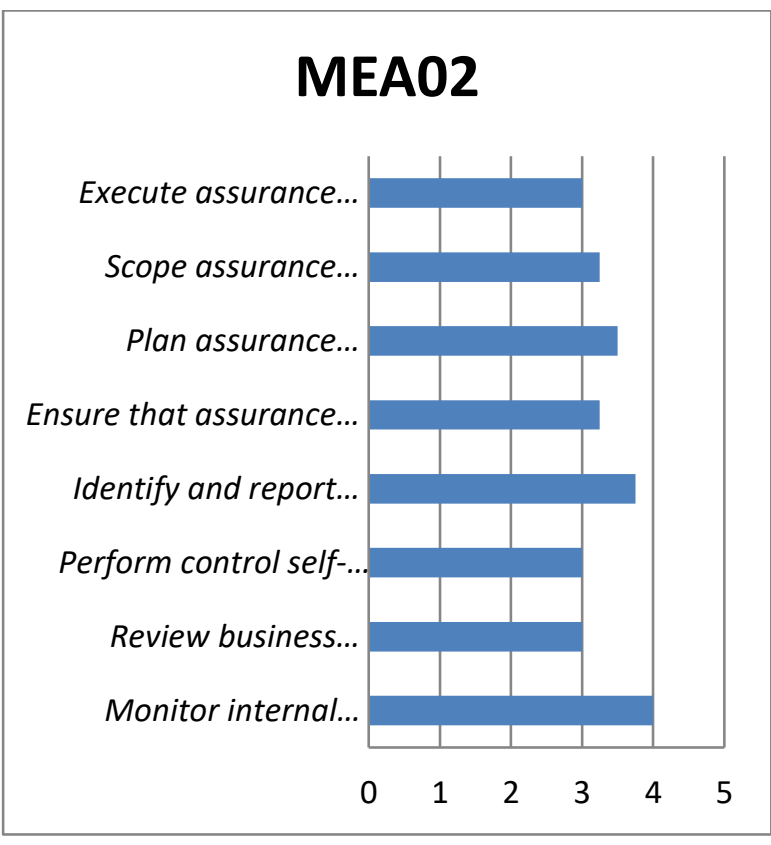

Gambar 5. Hasil Perhitungan Kuisioner MEA02 Dalam Grafik

Tabel 9. Hasil Perhitungan Kuisioner MEA03

\begin{tabular}{llc}
\hline Domain & Keterangan & Nilai \\
\hline MEA03.01 & $\begin{array}{l}\text { Identify external } \\
\text { compliance } \\
\text { requirements }\end{array}$ & 3.3 \\
\hline MEA03.02 & $\begin{array}{l}\text { Optimise response to } \\
\text { external requirements }\end{array}$ & 2.5 \\
\hline MEA03.03 & $\begin{array}{l}\text { Confirm external } \\
\text { compliance }\end{array}$ & 3.3 \\
\hline
\end{tabular}

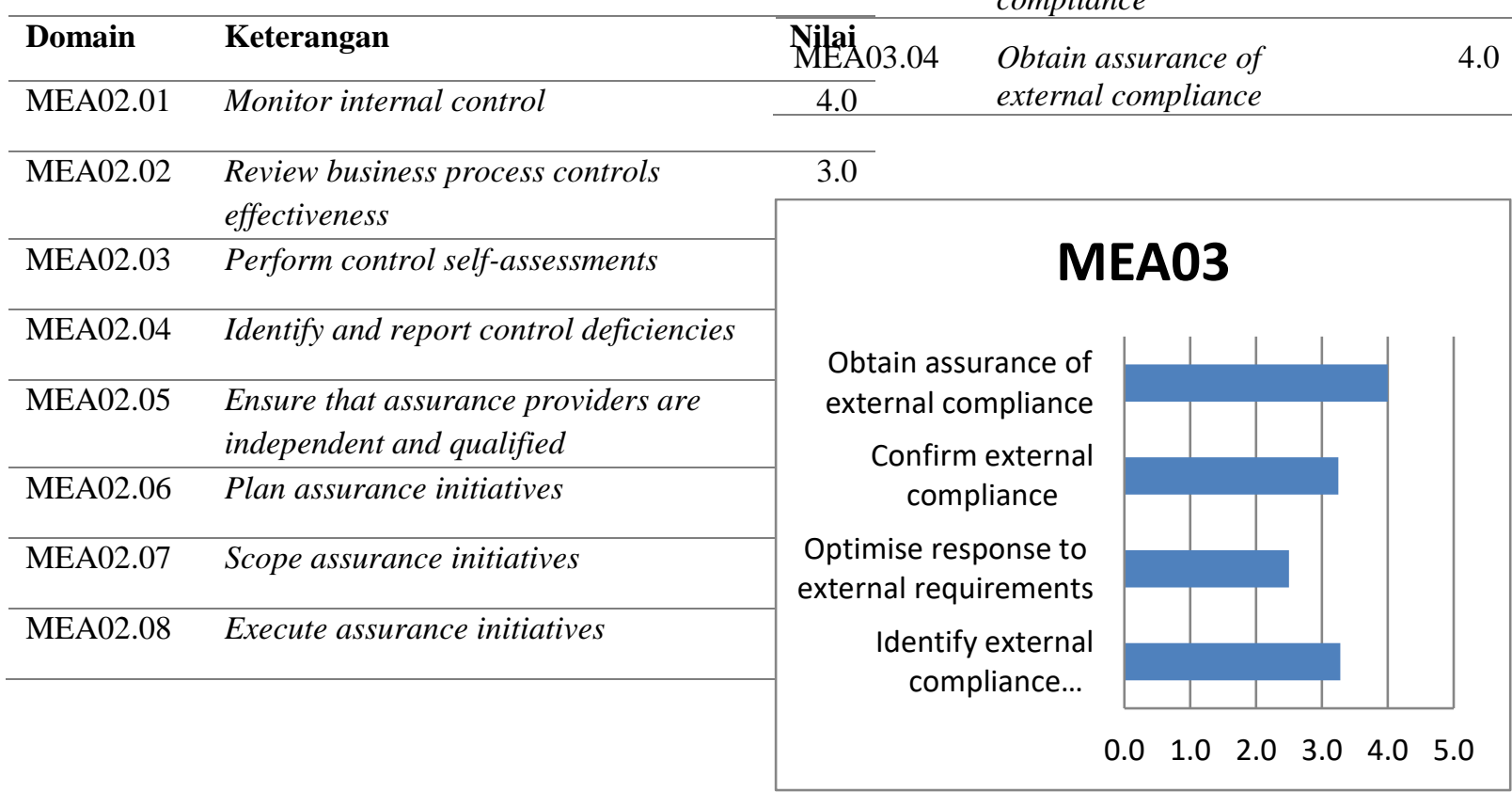

Gambar 6. Hasil Perhitungan Kuisioner MEA03 Dalam Grafik 


\subsection{Nilai Keseluruhan Domain MEA}

Nilai nilai rata-rata dari ke tiga sub domain, untuk mengetahui nilai keseluruhan dengan menggunakan rumus pada Persamaan, dengan perhitungan sebagai berikut:

$$
\begin{aligned}
& \text { Indeks }=\frac{\sum \text { Jawaban Kuisioner }}{\sum \text { Domain Proses }} \\
& =\frac{\sum \text { MEA01 }+\sum \text { MEA02 }+\sum \text { MEA03 }}{3} \\
& =\frac{3.2+3.3+3.3}{3} \\
& =3.3 .
\end{aligned}
$$

\begin{tabular}{|c|c|c|c|}
\hline Domain & Keterangan & Nilai & Kondisi \\
\hline MEA01 & $\begin{array}{l}\text { Monitor, Evaluate } \\
\text { and Assess } \\
\text { Perfomance and } \\
\text { Conformance }\end{array}$ & 3.2 & $\begin{array}{l}3= \\
\text { Established } \\
\text { process }\end{array}$ \\
\hline MEA02 & $\begin{array}{l}\text { Monitor, Evaluate } \\
\text { and Assess the } \\
\text { System of Internal } \\
\text { Control }\end{array}$ & 3.3 & $\begin{array}{l}3= \\
\text { Established } \\
\text { process }\end{array}$ \\
\hline MEA03 & $\begin{array}{l}\text { Monitor, Evaluate } \\
\text { and Assess } \\
\text { Compliance With } \\
\text { External } \\
\text { Requirement }\end{array}$ & 3.3 & $\begin{array}{l}3= \\
\text { Established } \\
\text { process }\end{array}$ \\
\hline Rata-rata & & 3.3 & $\begin{array}{l}3= \\
\text { Established } \\
\text { process }\end{array}$ \\
\hline
\end{tabular}

Tabel 10. Nilai Keseluruhan dan Kondisi Domain MEA saat ini

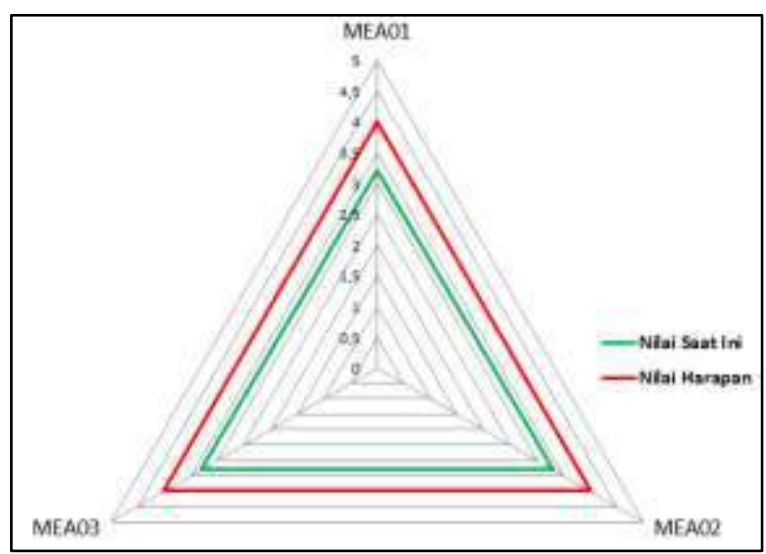

Gambar 7. Perbandingan Nilai Kematangan pada Domain MEA Saat Ini Dengan Nilai Kematangan Yang Diharapkan

\subsection{Analisis \\ Kesenjangan \\ dan Rekomendasi}

Tabel 11. Kesenjangan Tata Kelola Teknologi Informasi pada SIAK AIKOM untuk Domain MEA

\begin{tabular}{lccc}
\hline Domain & \multicolumn{3}{c}{ Tingkat Kematangan } \\
\cline { 2 - 4 } & Saat Ini & Diharapkan & Kesenjangan \\
\hline MEA & 3.3 & 4.0 & 0.7 \\
\hline
\end{tabular}

Kesenjangan ini dapat terjadi sebagai akibat adanya perbedaan dari apa yang diharapkan oleh stakeholder AIKOM Ternate dengan penilaian sesungguhnya terhadap pegawai. Tingkat kesenjangan adalah selisih antara nilai aktual dan nilai ekspektasi. Nilai kesenjangan yang diukur adalah kesenjangan tata kelola TI di bagian SIAK pada AIKOM Ternate berdasarkan framework COBIT 5.

\section{Kesimpulan}

Hasil analisis untuk tiga subdomain, yaitu MEA01, MEA02, dan MEA03 dapat disusun dalam bentuk tabel mengenai temuan

\begin{tabular}{|c|c|c|}
\hline \multicolumn{3}{|c|}{$\begin{array}{l}\text { Subdomain: MEA01 (Monitor, Evaluate and } \\
\text { Access Performance and Conformance) }\end{array}$} \\
\hline No & $\begin{array}{l}\text { Temuan } \\
\text { Masalah }\end{array}$ & Rekomendasi \\
\hline 1 & $\begin{array}{l}\text { Belum } \\
\text { memiliki } \\
\text { sistem } \\
\text { monitoring } \\
\text { dan } \\
\text { evaluasi } \\
\text { pada SIAK }\end{array}$ & $\begin{array}{l}\text { Menetapkan pedoman baru } \\
\text { SIAK baru tentang } \\
\text { Perencanaan SIAK, } \\
\text { Perancangan SIAK, Proses } \\
\text { Membangun SIAK, } \\
\text { Pelaksana Monitoring, } \\
\text { Evaluasi, dan Proses Kerja } \\
\text { pada SIAK. }\end{array}$ \\
\hline 2 & $\begin{array}{l}\text { Tidak } \\
\text { secara rutin } \\
\text { dilakukan } \\
\text { evaluasi } \\
\text { terhadap } \\
\text { indikator- } \\
\text { indikator } \\
\text { yang } \\
\text { digunakan }\end{array}$ & $\begin{array}{l}\text { DirekturAIKOM Ternate } \\
\text { harus memiliki sistem yang } \\
\text { jelas terhadap pemantauan } \\
\text { setiap tugas, contohnya } \\
\text { untuk Memastikan para } \\
\text { penanggung jawab evaluasi, } \\
\text { cara monitoring, meminta } \\
\text { laporan secara berkala } \\
\text { kepada penanggung jawab } \\
\text { tugas, dan Memberikan }\end{array}$ \\
\hline
\end{tabular}
masalah dan rekomendasinya seperti pada table 12 .

Tabel 12. Temuan Masalah dan Rekomendasinya 
tanggapan tehadap hasil laporan dari penanggung jawab tugas

\begin{tabular}{|c|c|c|}
\hline \multicolumn{3}{|c|}{$\begin{array}{l}\text { Subdomain: MEA01 (Monitor, Evaluate and } \\
\text { Access Performance and Conformance) }\end{array}$} \\
\hline No & $\begin{array}{l}\text { Temuan } \\
\text { Masalah }\end{array}$ & Rekomendasi \\
\hline 3 & $\begin{array}{l}\text { Setiap ada } \\
\text { perubahan } \\
\text { indikator } \\
\text { monitoring } \\
\text { dan } \\
\text { evaluasi } \\
\text { tidak selalu } \\
\text { dikomunika } \\
\text { sikan } \\
\text { kepada } \\
\text { stakeholder }\end{array}$ & $\begin{array}{l}\text { DirekturAIKOM Ternate } \\
\text { harus memiliki sistem yang } \\
\text { jelas terhadap pemantauan } \\
\text { setiap tugas, contohnya } \\
\text { untuk Memastikan para } \\
\text { penanggung jawab evaluasi, } \\
\text { cara monitoring, meminta } \\
\text { laporan secara berkala } \\
\text { kepada penanggung jawab } \\
\text { tugas, dan Memberikan } \\
\text { tanggapan tehadap hasil } \\
\text { laporan dari penanggung } \\
\text { jawab tugas }\end{array}$ \\
\hline 4 & $\begin{array}{l}\text { Data yang } \\
\text { digunakan } \\
\text { untuk } \\
\text { memonitor } \\
\text { SIAK } \\
\text { belum } \\
\text { secara } \\
\text { keseluruhan } \\
\text { dievaluasi } \\
\text { kebenarann } \\
\text { ya }\end{array}$ & $\begin{array}{l}\text { Direktur AIKOM Ternate } \\
\text { perlu selalu melakukan } \\
\text { pengecekan data yang } \\
\text { diterima melalui sumber } \\
\text { data khusus, sehingga Unit } \\
\text { IT perlu dibentuk }\end{array}$ \\
\hline 5 & $\begin{array}{l}\text { Hasil } \\
\text { laporan } \\
\text { berkala } \\
\text { monitoring } \\
\text { dan } \\
\text { evaluasi } \\
\text { SIAK tidak } \\
\text { selalu dapat } \\
\text { dipahami } \\
\text { oleh } \\
\text { pimpinan } \\
\text { AIKOM } \\
\text { Ternate }\end{array}$ & \\
\hline 6 & $\begin{array}{l}\text { Belum } \\
\text { adaUnit IT } \\
\text { beserta } \\
\text { sumber } \\
\text { daya } \\
\text { manusia } \\
\text { yang } \\
\text { bertanggun }\end{array}$ & $\begin{array}{l}\text { Jajaran pimpinan di AIKOM } \\
\text { Ternate segera menentukan } \\
\text { SDM untuk membentuk } \\
\text { Unit IT dengan memberikan } \\
\text { surat tugas secara resmi } \\
\text { untuk menangani perbaikan }\end{array}$ \\
\hline
\end{tabular}

g jawab khusus dari hasil monitoring dan

untuk

monitoring

dan

evaluasi,

sehingga

pengemban

gan

monitoring

dan

evaluasi

SIAK tidak

sesuai

dengan

tujuan

AIKOM

Ternate

7 Hasil

perbaikan

dari

evaluasi

tidak selalu

dilaporakan

kepada

pimpinan

AIKOM

Ternate

Subdomain: MEA02 (Monitor, Evaluate and Assess the System of Internal Control)

\begin{tabular}{|c|c|c|}
\hline No & $\begin{array}{l}\text { Temuan } \\
\text { Masalah }\end{array}$ & Rekomendasi \\
\hline 1 & $\begin{array}{l}\text { Belum ada } \\
\text { tindakan } \\
\text { evaluasi } \\
\text { oleh jajaran } \\
\text { pimpinan } \\
\text { terhadap } \\
\text { pengontrola } \\
\text { n SIAK }\end{array}$ & $\begin{array}{l}\text { AIKOM Ternate harus } \\
\text { menyusun mekanisme } \\
\text { proses pengontrolan SIAK } \\
\text { yang ditetapkan berdasarkan } \\
\text { SOP untuk Unit IT yang } \\
\text { berisi tentang Unit IT } \\
\text { meminta feedback kepada } \\
\text { pengguna SIAK, }\end{array}$ \\
\hline 2 & $\begin{array}{l}\text { Unit IT } \\
\text { belum } \\
\text { dibentuk } \\
\text { dan perlu } \\
\text { memiliki } \\
\text { kriteria- } \\
\text { kriteria } \\
\text { penilaian } \\
\text { mandiri } \\
\text { terhadap } \\
\text { SIAK }\end{array}$ & $\begin{array}{l}\text { menganalisis hasil feedback, } \\
\text { melaporkan hasil analisis } \\
\text { kepadaDirektur AIKOM } \\
\text { Ternate, jajaran pimpinan } \\
\text { membaca hasil analisis, dan } \\
\text { kemudian dapat memberikan } \\
\text { instruksi, Unit IT } \\
\text { melaksanakan intruksi dari } \\
\text { jajaran pimpinan untuk } \\
\text { perbaikan, dan Jika dalam } \\
\text { penanganan feedback ada }\end{array}$ \\
\hline
\end{tabular}




$\begin{array}{lll}3 & \text { Belum } & \text { perubahan dalam fitur atau } \\ \text { adanya } & \text { sistem SIAK, maka Unit IT } \\ \text { kebijakan } & \text { akan melakukan soasialisasi } \\ \text { dan SOP } & \text { perubahan kepada pengguna } \\ \text { yang } & \text { SIAK } \\ \text { mengatur } & \\ \text { rencana dan } & \\ \text { kriteria- } & \\ \text { kriteria } & \\ \text { mandiri } & \\ \text { terhadap } & \\ \text { SIAK } & \end{array}$

\section{Subdomain: MEA02 (Monitor, Evaluate and} Assess the System of Internal Control)

\begin{tabular}{|c|c|c|}
\hline No & $\begin{array}{l}\text { Temuan } \\
\text { Masalah }\end{array}$ & Rekomendasi \\
\hline 4 & $\begin{array}{l}\text { Belum } \\
\text { memiliki } \\
\text { pedoman } \\
\text { pelaksanaa } \\
\mathrm{n} \\
\text { penjaminan } \\
\text { mutu SIAK } \\
\text { yang nanti } \\
\text { menjadi } \\
\text { tugas Unit } \\
\text { IT yang } \\
\text { akan } \\
\text { dibentuk }\end{array}$ & \multirow[t]{3}{*}{$\begin{array}{l}\text { Menyusun standar } \\
\text { penjaminan mutu SIAK } \\
\text { berdasarkan Rencana } \\
\text { Strategi AIKOM Ternate. } \\
\text { Penyusunan standar } \\
\text { penjamin mutu harus ada } \\
\text { tindak lanjut dengan } \\
\text { lembaga penjaminan mutu } \\
\text { pada AIKOM Ternate yaitu } \\
\text { LPMI, yang mana jajaran } \\
\text { pimpinan AIKOM Ternate } \\
\text { harus memastikan bahwa } \\
\text { standar penjaminan mutu } \\
\text { SIAK dibuat, disahkan dan } \\
\text { dilaksanakan }\end{array}$} \\
\hline 5 & $\begin{array}{l}\text { Belum } \\
\text { adanya } \\
\text { pedoman } \\
\text { dan SOP } \\
\text { dari } \\
\text { pelaksanaa } \\
\text { n } \\
\text { penjaminan } \\
\text { mutu SIAK }\end{array}$ & \\
\hline 6 & $\begin{array}{l}\text { Penjaminan } \\
\text { mutu yang } \\
\text { ada belum } \\
\text { sepenuhnya } \\
\text { selaras } \\
\text { dengan } \\
\text { kebutuhan } \\
\text { AIKOM } \\
\text { Ternate }\end{array}$ & \\
\hline 7 & $\begin{array}{l}\text { Tidak } \\
\text { adanya } \\
\text { evaluasi } \\
\text { cara } \\
\text { penjaminan }\end{array}$ & $\begin{array}{l}\text { AIKOM Ternate perlu } \\
\text { melaksanakan evaluasi } \\
\text { secara berkala terhadap } \\
\text { pelaksanaan penjaminan } \\
\text { mutu SIAK. LPMI memiliki }\end{array}$ \\
\hline
\end{tabular}

mutu SIAK penjadwalan audit tahunan secara terhadap proses kerja setiap berkala bidang. Proses selanjutnya

8 Hasil jajaran pimpinan AIKOM pelaksanaa Ternate perlu melakukan n audit terhadap LPMI itu penjaminan sendiri termasuk semua mutu tidak selalu standar penjamin mutu yang

disusun

dalam

bentuk laporan

9 Hasil evaluasi pelaksanaa $\mathrm{n}$ penjamin mutu tidak dievaluasi secara berkala

\begin{tabular}{|c|c|c|}
\hline \multicolumn{3}{|c|}{$\begin{array}{l}\text { Subdomain: MEA03 (Monitor, Evaluate and } \\
\text { Assess Compliance With External Requirement) }\end{array}$} \\
\hline No & $\begin{array}{l}\text { Temuan } \\
\text { Masalah }\end{array}$ & Rekomendasi \\
\hline 1 & $\begin{array}{l}\text { AIKOM } \\
\text { Ternate } \\
\text { belum } \\
\text { memiliki } \\
\text { mekanisme } \\
\text { untuk } \\
\text { menidentifi } \\
\text { kasi } \\
\text { perubahan- } \\
\text { perubahan } \\
\text { dari pihak } \\
\text { ekternal }\end{array}$ & $\begin{array}{l}\text { Membuat SOP mekanisme } \\
\text { pengontrolan SIAK (seperti } \\
\text { pada penjelasan } \\
\text { rekomendasi MEA02) } \\
\text { terkait perubahan-perubahan } \\
\text { SIAK berdasarkan } \\
\text { perubahan eksternal }\end{array}$ \\
\hline 2 & $\begin{array}{l}\text { Belum ada } \\
\text { kebijakan } \\
\text { dan SOP } \\
\text { untuk } \\
\text { mengikuti } \\
\text { perubahan- } \\
\text { perubahan } \\
\text { dari pihak } \\
\text { eksternal }\end{array}$ & \\
\hline 3 & $\begin{array}{l}\text { Kriteria } \\
\text { SIAK } \\
\text { belum } \\
\text { sepenuhnya } \\
\text { disesuaikan } \\
\text { dengan }\end{array}$ & \\
\hline
\end{tabular}


sistem

informasi

akademik

yang sudah

ditetapkan

Dari tabel 12 di atas, peneliti dapat berkesimpulan bahwa ini:

1. Berdasarkan hasil klasifikasi pernyataan dari framework COBIT 5 maka penulis memilih domain MEA dengan Sub Domain MEA01, MEA02 dan MEA03 dan setiap sub domain terdapat 17 kontrol proses TI.

2. Berdasarkan hasil penelitian dengan menggunakan framework COBIT 5 pada domain Monitoring, Evaluating and Assess (MEA) dihasilkan nilai MEA01 (Performance and Conformance) sebesar 3.2, nilai MEA02 (The System of Internal Control) sebesar 3.3, dan nilai MEA03 (Compiance with External Requirent) sebesar 3.3, yang mana untuk tiga subdomain tersebut berada pada tingkat Established Process.

3. Hasil yang dapat direkomendasikan untuk subdomain MEA01 adalah menetapkan pedoman dan SOP pelaksanaan monitoring dan evaluasi terhadap SIAK, perlu adanya monitoring dari pimpinan terhadap tugas dari masing-masing stakeholder serta menetapkan stadar proses pelaporan dari pengempulan data, waktu dan feedback dari hasil laporan. Rekomendasi untuk MEA02 adalah AIKOM Ternate harus menyusun mekanisme proses pengontrolan SIAK, menyusun standar penjaminan mutu SIAK, dan melaksanakan evaluasi secara berkala terhadap penjaminan mutu. Dan rekomendasi untuk MEA03 adalah melakukan peninjauan ulang secara berkala dan membuat pedoman dan SOP terkait perubahan SIAK berdasarkan perubahan eksternal.

\section{Saran}

Berkaitan dengan hasil penelitian untuk domain MEA, penulis dapat menyampaikan beberapa saran sebagai berikut:

1. Melakukan audit tata kelola teknologi informasi dengan menggunakan domain yang lain, misal domain Deliver, Service and Support (DSS) untuk dapat melakukan audit pengelolaan layanan maupun insiden (subdomain DSS02), ataupun melakukan audit pada pengelolaan keberlangsungan sistem (subdomain DSS04), ataupun audit pada pengelolaan pengendalian proses bisnis (subdomain DSS06).

2. Melakukan identifikasi awal melalui wawancara terlebih dahulu dengan stakeholder untuk menentukan domain yang akan digunakan, sebab saat ini penulis langsung menentukan audit dengan domain DSS.

\section{Daftar Pustaka}

[1] Supriyaddin, W. W. Winarno, and M. R. Arief, "Evaluasi tata kelola teknologi informasi menggunakan metode cobit 5 di stkip taman siswa bima," J. Inf. Politek. Indonusa Surakarta, vol. 3, 2017.

[2] ISACA, COBIT 5 A Business Framework for the Governance and Management of Enterprise IT. USA: IT Governance Institute, 2012.

[3] ISACA, COBIT 5 Enabling Processes. USA: IT Governance Institute, 2012. 